\title{
Apa Saya Khawatir Karena Fear of Negative Evaluation? Sebuah Studi Pada Remaja
}

\author{
Kokoh Dwi Putera $^{(1)}$, Muhammad Salis Yuniardi ${ }^{(2)}$, Alifah Nabilah Masturah ${ }^{(3)}$ \\ ${ }^{(1),(2),(3)}$ Fakultas Psikologi, Universitas Muhammadiyah Malang, Malang, Indonesia \\ Adolescence is a period characterised by teenagers' feelings that problems in life are much \\ more complicated than the periods that come before (childhood) or after it (adulthood). This is \\ the case particularly because adolescence lasts quickly and many changes occur during the \\ period. One of the prevalent disorders commonly experienced by adolescents is generalized \\ anxiety disorder $(G A D)$. We assumed in the present research that fear of negative evaluation \\ (FNE) may influence the GAD. Building upon this assumption, the goal of this research was to \\ examine the extent to which FNE explains GAD. Participants were 475 students from 9 high \\ schools in Malang, who were recruited based on probability or random sampling. The data \\ were then analysed quantitatively using simple linear regression. The results showed that FNE \\ was a significant positive predictor of GAD, implying that the high levels of FNE were related \\ to high levels of GAD, and, vice versa, low levels of FNE were related to low levels of GAD.
}

Keywords: adolescents, fear of negative evaluation, generalized anxiety disorder

Masa remaja adalah masa dimana setiap problematika hidup terasa lebih berat daripada masamasa sebelum (kanak-kanak) atau setelahnya (dewasa). Hal ini dikarenakan masa remaja berlangsung dengan cepat dan ditandai dengan banyak perubahan. Salah satu gangguan yang prevalensinya cukup tinggi yang dialami oleh remaja adalah generalized anxiety disorder (GAD). Peneliti mengasumsikan bahwa fear of negative evaluation (FNE) dapat mempengaruhi GAD tersebut. Mengacu pada asumsi ini, tujuan dari penelitian ini adalah untuk menguji sejauh mana FNE dapat mempengaruhi GAD. Subjek penelitian adalah 475 siswa dan siswi dari 8 SMA di Kota Malang, yang direkrut atas dasar probability sampling. Data kemudian dianalisis secara kuantitatif menggunakan regresi linear sederhana (simple linear regression). Hasil penelitian menunjukkan bahwa FNE menjadi prediktor positif yang signifikan dalam menjelaskan GAD. Dengan demikian dapat disimpulkan bahwa semakin tinggi FNE maka akan semakin tinggi juga GAD, begitupun sebaliknya jika semakin rendah FNE maka akan semakin rendah juga GAD.

Kata Kunci: fear of negative evaluation, generalized anxiety disorder, remaja

MEDIAPSI, 2020, Vol. 6(1), 17-25, DOI: https://doi.org/10.21776/ub.mps.2020.006.01.3

Received: 05-05-2019. Revised: 11-09-2019. Accepted: 07-04-2020. Published online: 12-06-2020

Handling Editor: Intan Rahmawati, Universitas Brawijaya, Malang, Indonesia

*Corresponding author: Kokoh Dwi Putera, Fakultas Psikologi, Universitas Muhammadiyah Malang, Indonesia.

E-mail: kokohputera@gmail.com

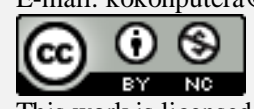

This work is licensed under a Creative Commons Attribution-NonCommercial 4.0 International License.

How to cite this article in accordance with the American Psychological Association (APA) $6^{\text {th }}$ guidelines:

Putera, K. D., Yuniardi, M. S., \& Masturah, A. N. (2020). Apa saya khawatir karena fear of negative evaluation?

Sebuah studi pada remaja. MEDIAPSI, 6(1), 17-25. https://doi.org/10.21776/ub.mps.2020.006.01.3

\section{Pendahuluan}

Santrock (2013) mendeskripsikan remaja sebagai individu yang berada pada kisaran usia 15 hingga 18 tahun. Banyak perubahan yang terjadi pada diri remaja, baik secara biologis, kognitif, maupun sosio-emosional. Salah satu tuntutan saat memasuki masa remaja adalah kemandirian (Supingah, 2018). Hal ini berarti 
bahwa remaja dituntut untuk memutuskan segala sesuatu dengan tepat dan benar. Di beberapa kasus, seorang remaja tidak mampu untuk mengatasi tuntutan maupun perubahanperubahan yang terjadi pada dirinya. Konflik internal seorang remaja dan lingkungan sosialnya dapat menyebabkan ketidakstabilan yang berdampak pada munculnya gejala-gejala gangguan psikologis.

Berangkat dari 17 poin dalam Sustainable Development Goals dari WHO atau World Health Organization ("World health statistics 2017: Monitoring health for the SDGs, sustainable development goals", 2017), masih banyak pekerjaan rumah yang harus dikerjakan oleh setiap negara untuk membangun kemaslahatan masyarakatnya. Salah satu poin yang diangkat adalah mengenai hidup sehat dan kesejahteraan hidup masyarakat di setiap kelompok usia. Hal ini menyebabkan remaja termasuk salah satu yang menjadi target pembangunan yang berkelanjutan tersebut. Selain itu, data menunjukkan bahwa jumlah remaja usia 15 hingga 19 tahun di dunia per Januari 2018 adalah 603 juta jiwa, yang tergolong tinggi dari total 7.53 miliar penduduk dunia di setiap kelompok usia ("2018, Jumlah penduduk Indonesia mencapai 265 juta jiwa", 2018).

Dengan banyak perubahan yang terjadi dalam diri seorang remaja, kemungkinan individu mengalami gangguan psikologis semakin terbuka. Tinjauan prevalensi pada remaja umumnya dilandaskan pada generalized anxiety disorder (GAD). Orang yang mengalami GAD tidak mengetahui bagaimana cara untuk menghentikan kecemasan yang timbul, walaupun mereka menyadari bahwa situasi sosial yang dihadapi merupakan situasi normal (Behar, DiMarco, Hekler, Mohlman, \& Staples, 2009). Kecemasan dan kekhawatiran yang berlebihan biasanya berlangsung lama dan menetap setidaknya enam bulan sehingga menggangu aktivitas maupun kegiatan-kegiatan yang dilakukan oleh orang tersebut (Badan Penelitian dan Pengembangan Kesehatan
Kementerian Kesehatan RI, 2013). Hal ini menjadikan kekhawatiran sebagai indikator utama dalam GAD.

Pada dasarnya, GAD merupakan gangguan yang sangat umum. Sekitar 5\% dari seluruh populasi dunia mengalami GAD dalam hidupnya menurut Wittchen dan Hoyer (dalam Hanisch, 2019). Sedangkan menurut laporan WHO ("World health statistics 2017: Monitoring health for the SDGs, sustainable development goals", 2017), populasi yang mengalami gangguan kecemasan di wilayah Asia Tenggara mencapai angka 23\%, sebuah prosentase yang tertinggi dibanding wilayah di benua-benua lain. Artinya, Indonesia juga termasuk ke dalam kategori yang tinggi berkaitan dengan gangguan kecemasan secara keseluruhan.

Remaja, seperti yang disebutkan diatas, merupakan fase transisi dari masa kanak-kanak menuju dewasa. Menurut Beesdo, Knappe dan Pine (2009), anak-anak dapat memanifestasikan banyak ketakutan dan kecemasan sebagai bagian dari perkembangan mereka. Kecemasan yang dialami oleh anak biasanya berupa reaksi takut terhadap kegelapan, pertemuan dengan lingkungan baru, perpisahan dengan orang tua, dan lain sebagainya. Ketika anak memasuki masa remaja, kecemasan yang mereka alami biasanya berupa reaksi atas perubahanperubahan pada dirinya, tekanan berlebih, perasaan malu atau takut atas penilaian negatif oleh orang lain, baik berkaitan dengan penilaian fisik maupun prestasi. Remaja yang mengalami kecemasan memiliki resiko kehilangan motivasi dalam berprestasi, merasa tidak berharga, dan mengalami gangguan psikologis yang dapat mengganggu hidup mereka, yang termanifestasi dalam depresi dan GAD (Bernstein, Targownik, Sexton, Graff, Miller \& Walker, 2016).

Remaja yang mengalami GAD sering merasa terbelenggu dalam kekhawatiran terhadap kesuksesan dan kemampuan mereka untuk mendapatkan pengakuan dari orang lain. Ada tuntutan berlebih yang muncul dalam diri mereka karena ketidakinginan mereka untuk 
gagal, ditolak, dihina ataupun diejek oleh lingkungan sosialnya. Tekanan ini berjalan lurus dengan keragu-raguan yang juga berkembang dalam diri mereka sehingga mereka terlalu berlebihan dalam menilai kelemahan yang ada dalam diri mereka, yang berimbas pada ketidakyakinan mereka pada diri sendiri.

\section{American Psychological Association} (APA, 2016) menyebutkan bahwa anak terkadang memiliki kecemasan dan kekhawatiran tinggi selama berhari-hari. Kecemasan ini terjadi pada dua atau lebih situasi atau interaksi, serta menunjukkan setidaknya satu gejala fisik yang muncul pada mereka, seperti: mudah lelah, sulit berkonsentrasi, otot tegang, amarah mudah meluap, dan sulit tidur. Gejala-gejala ini setidaknya terjadi selama 6 bulan. Gangguan kecemasan pada remaja dalam APA (2016) memiliki angka $11 \%$. Selain itu, diestimasikan juga bahwa antara 15\% hingga 30\% dari anakanak dan remaja didiagnosa mengalami gangguan kecemasan di beberapa waktu tertentu di masa kanak-kanak mereka Dengan total remaja dunia yang tergolong tinggi, prevalensi gangguan kecemasan tersebut pun juga tinggi.

Ada beberapa gejala GAD, diantaranya adalah merasa kurang istirahat atau merasakan tegang saraf, cepat lelah, susah berkonsentrasi, mudah marah, tegang otot dan susah tidur (De Santis, Iovine, Brancaleone, Esposito \& Buffardi, 2012). Kecemasan, kekhawatiran atau gejala-gejala fisik yang terjadi dapat menyebabkan distress tingkat tinggi atau penurunan motivasi untuk berhubungan sosial, yang membuat orang yang mengalaminya merasakan kesulitan-kesulitan lain dalam hidup. Individu yang mengalami kecemasan sosial akan berusaha keras untuk menjauhi kondisikondisi yang dapat membuatnya cemas (Yuniardi, 2017).

GAD dari pemaparan-pemaran di atas dapat disimpulkan sebagai sebuah kecenderungan gangguan kecemasan yang sangat berpengaruh negatif terhadap perkembangan individu. Dalam hal ini, kecemasan dapat disebabkan oleh faktor internal dan faktor eksternal. Faktor eksternal merupakan faktor yang berasal dari luar diri individu. Faktor eksternal ini berupa situational setting, atau hal-hal yang secara alami memang akan selalu berjalan dan tidak dapat ditebak. Faktor internal, sementara itu, merupakan faktor yang berasal dari dalam diri individu. Faktor internal secara erat berkaitan dengan pemikiran-pemikiran yang muncul karena situasi eksternal, baik berupa pemikiranpemikiran yang positif maupun negatif.

Dalam hal ini APA (2016) memaparkan data bahwa GAD memiliki beberapa gejala psikologis, yang salah satunya adalah kekhawatiran yang tidak terkontrol. Individu yang memiliki kekhawatiran tinggi tentu akan mengalami kecenderungan lebih besar untuk terganggu dalam melakukan aktivitas sosial sehari-hari. Karena manusia adalah makhluk sosial maka peran serta lingkungan dan orangorang disekitar berpengaruh terhadap perkembangan hidup individu. Ketika seseorang sudah mengalami kekhawatiran maka kecenderungannya untuk mengalami gangguan psikologis berupa kecemasan juga bertambah tinggi. Kekhawatiran dapat terjadi karena banyak hal, yang salah satunya adalah khawatir atau takut atas kritikan.

Ketakutan terhadap kritik dan penilaian negatif dari orang lain dikenal dengan nama fear of negative evaluation (FNE). Dilihat dari ciri-cirinya, menurut Atasoy, Donnelly dan Pearson (2016) individu dengan kecenderungan FNE tinggi mengalami perasaan malu, jantung berdebar-debar, berkeringat dan gemetar. Individu yang mengalami FNE akan menghindari kontak mata secara langsung dengan lawan bicaranya serta mengalami peningkatan denyut jantung (Chen dkk., 2018). Hal ini menyebabkan penderita FNE akan mengalami kesulitan dalam berkomunikasi.

Individu yang mengalami FNE cenderung pasif dan pemalu ketika berhadapan 
dengan lingkungan sosialnya. Hal ini dikarenakan individu yang memiliki harga diri rendah memiliki kepercayaan diri yang rendah juga. Freud (dalam Sutrisno, 2013) membedakan tiga jenis kecemasan, yaitu kecemasan objektif, kecemasan neurotik, dan kecemasan moral. Kecemasan-kecemasan ini menurunkan kepercayaan diri seseorang, yang mengakibatkan orang tersebut mengalami kecemasan, dan dalam jangka panjang kecemasan ini menimbulkan GAD.

Atas dasar pemaparan-pemaparan diatas, dapat ditarik kesimpulan bahwa FNE bisa berpengaruh terhadap GAD. FNE merupakan variabel kognitif, sedangkan GAD merupakan variabel perilaku. Apabila GAD muncul karena sebuah kecemasan berlebih, maka FNE bisa menjadi salah satu kecemasan yang dialami oleh individu. Penelitian terdahulu oleh Yuniardi (2017) menunjukkan bahwa FNE dapat mempengaruhi timbulnya social anxiety, sedangkan social anxiety sendiri merupakan gangguan yang berada dalam satu kategori yang sama dengan GAD.

Paparan di atas mendasari peneliti untuk berasumsi bahwa FNE memiliki pengaruh terhadap munculnya kecenderungan GAD. Selain itu, tidak banyak referensi dari Indonesia yang membahas keterkaitan antara FNE dengan GAD. Untuk mengisi gap tersebut, penelitian ini bertujuan untuk menguji peran FNE terhadap GAD pada remaja.

\section{Metode}

\section{Partisipan dan desain penelitian}

Subjek penelitian adalah 475 murid SMA di Malang (laki $=173$, perempuan $=302$; usia bervariasi dari 16 tahun sampai dengan 18 tahun). Alasan pemilihan subjek adalah karena peneliti berasumsi bahwa siswa SMA memiliki banyak perubahan pada dirinya, baik perubahan fisik, kognitif, maupun sosio-emosional. Hal inilah yang menyebabkan pemilihan subjek dirasa tepat dan sesuai dengan tema dari penelitian ini. Adapun subjek dalam penelitian ini berjumlah 475 siswa yang diambil secara acak dari 8 SMA berbeda di Kota Malang, yakni SMA Negeri 7, SMA Negeri 5, SMA Negeri 8, MAN 1, MAN 2, SMK Negeri 3, SMK Negeri 4, dan SMKS Muhammadiyah 2.

Teknik pengambilan sampel pada penelitian ini menggunakan random sampling. Menurut Kumar (2005), random sampling adalah teknik penentuan sampel secara acak. Hal ini berarti bahwa teknik random sampling memungkinkan setiap subjek memiliki kesempatan yang sama untuk terpilih sebagai sampel dari penelitiaan.

Penelitian ini menggunakan penelitian kuantitatif korelasional cross-sectional. Berdasarkan desain penelitian ini, peran variabel bebas $(\mathrm{X})$ atau independen terhadap variabel dependen atau terikat (Y) diuji melalui pengukuran atau pengamatan yang dilakukan sekali sesuai dengan waktu yang ditentukan oleh peneliti (Sugiyono, 2011). Dalam penelitian ini, FNE adalah variabel independen atau terikat, sementara GAD adalah variabel dependen atau tergantung.

\section{Prosedur dan pengukuran}

Terdapat dua skala yang digunakan dalam penelitian ini. Pertama adalah skala untuk mengukur fear of negative evaluation (FNE), yang didasarkan pada skala BFNE (Brief of Negative Evaluation; Watson \& Friend, 1969). Skala BFNE mengandung aspek-aspek atau indikator seperti kekhawatiran individu mengenai penilaian dari orang lain mengenai dirinya, stres individu akibat penilaian negatif dari orang lain, penghindaran individu terhadap situasi yang dapat menyebabkan dirinya dievaluasi, harapan individu bahwa orang lain akan menilai dirinya secara negatif. Menurut versi aslinya, skala BFNE terdiri dari 12 item. Dalam penelitian ini, skala BFNE yang digunakan terdiri dari 8 item (BFNE-S; $\alpha=0.92$ ), yang didasarkan pada hasil penelitian oleh Yuniardi (2017). Sementara itu, generalized anxiety disorder GAD diukur dengan skala PSWQ (The Penn State Worry Questionnaire), yang didasarkan pada hasil 
penelitian oleh Yuniardi (2017). Skala PSWQ dalam penelitian ini terdiri dari 16 aitem $(\alpha=$ 0.85), yang mengukur sejauh mana remaja merasakan kekhawatiran yang berlebihan dan terus menerus.

Model skala yang digunakan dalam penelitian ini adalah model skala Likert. Menurut Djaali (2008), skala Likert adalah skala yang dapat digunakan untuk mengukur sikap, pendapat, dan persepsi seseorang atau sekelompok orang tentang suatu gejala atau fenomena. FNE menggunakan lima format pilihan dengan rentang Sangat Tidak Sesuai (STS), Tidak Sesuai (TS), Ragu-Ragu (R), Sesuai (S) dan Sangat Sesuai (SS). Terdapat pertanyaan yang bersifat mendukung (favorable), dan tidak mendukung (unfavorable).

GAD menggunakan lima format pilihan dengan rentang Sangat Tidak Sesuai (STS), Tidak Sesuai (TS), Ragu-Ragu (R), Sesuai (S) dan Sangat Sesuai (SS). Skala ini juga terdiri dari aitem yang bersifat mendukung (favorable) maupun tidak mendukung (unfavorable).

Dalam penelitian ini, prosedur yang dilakukan ada tiga tahapan utama, yaitu tahap persiapan, tahap pelaksanaan, dan tahap analisa data.

Tahap persiapan dimulai ketika peneliti melakukan pendalaman materi melalui kajian teoritik. Peneliti menyiapkan alat ukur berdasarkan aspek-aspek variabel. Instrumen penelitian yang digunakan berupa BFNE-S (Brief of Negative Evaluation Short Version) dan PSWQ (Penn State Worry Questionnaire), yang keduanya diadaptasi dari penelitian Yuniardi (2017). Instrumen ini tidak memerlukan try out untuk menguji kelayakan skala karena validitas tiap aitem dan reliabilitasnya sudah terbukti dari beberapa penelitian sebelumnya. Try out hanya dilakukan untuk mengetahui rata-rata lama pengerjaan skala dan pemahaman responden pada tiap aitem. Try-out dilakukan pada 14 responden secara online pada remaja berusia antara 14-18 tahun yang sedang menempuh pendidikan menengah atau sederajat. Selanjutnya peneliti meminta izin untuk melakukan penelitian, dan data yang diperoleh kemudian dianalisis menggunakan Statistical Package for Social Science (SPSS) versi 21.

Pada tahap pelaksanaan, peneliti menyebarkan dua skala, $B F N E-S$ dan skala $P S W Q$, pada subjek remaja yang memenuhi persyaratan sesuai dengan karakteristik sampel. Skala diberikan secara online. Meskipun demikian, untuk mengantisipasi keterbatasan jaringan internet atau device para responden, skala cetak juga disediakan.

Pada tahap analisa, data-data yang telah diperoleh kemudian diinput dan diolah atas dasar analisis regresi linear sederhana menggunakan SPSS 21. Dalam analisis ini, fear of negative evaluation (FNE) ditetapkan sebagai prediktor (independent variable), sementara generalized anxiety disorder (GAD) ditetapkan sebagai kriteria (dependent variable).

\section{Hasil}

Hasil uji Kolmogorov-Smirmov menunjukkan bahwa variabel FNE berdistribusi normal, $z=1.069, p>0.05$, begitupun juga variabel $\mathrm{GAD}, z=0.855, p>.05$.

Tabel 1. Kategorisasi Fear of Negative Evaluation (FNE) dan Generalized Anxiety Disorder (GAD)

\begin{tabular}{|c|c|c|c|c|c|c|}
\hline Variabel & Kategori & Interval & \multicolumn{2}{|c|}{ Frekuensi } & \multicolumn{2}{|c|}{ Persentase } \\
\hline \multirow[b]{2}{*}{ FNE } & Rendah & $0-15$ & 226 & $\begin{array}{l}\text { (L)91 } \\
\text { (P)135 }\end{array}$ & $\begin{array}{c}47,6 \\
\%\end{array}$ & $\begin{array}{l}\text { (L) } 19.2 \% \\
\text { (P) } 28.4 \%\end{array}$ \\
\hline & Tinggi & $16-32$ & 249 & $\begin{array}{l}\text { (L)82 } \\
\text { (P) } 167\end{array}$ & $\begin{array}{c}52,4 \\
\%\end{array}$ & $\begin{array}{l}\text { (L) } 17.3 \% \\
\text { (P) } 35.1 \%\end{array}$ \\
\hline \multirow[b]{2}{*}{ GAD } & Rendah & $0-31$ & 80 & $\begin{array}{l}\text { (L)34 } \\
\text { (P)46 }\end{array}$ & $\begin{array}{c}16,8 \\
\%\end{array}$ & $\begin{array}{l}\text { (L)7.1\% } \\
\text { (P) } 9.7 \%\end{array}$ \\
\hline & Tinggi & $32-64$ & 395 & $\begin{array}{l}\text { (L)139 } \\
\text { (P) } 256\end{array}$ & $\begin{array}{c}83,2 \\
\%\end{array}$ & $\begin{array}{l}\text { (L) } 29.3 \% \\
\text { (P) } 53.9 \%\end{array}$ \\
\hline
\end{tabular}

Berdasarkan Tabel 1 di atas, siswa lakilaki adalah subjek penelitian yang cenderung memiliki tingkat FNE dan GAD yang tinggi. 
Tabel 2. Hasil Uji Regresi Linear Sederhana untuk Menguji Peran Fear of Negative Evaluation (FNE) terhadap Generalized Anxiety Disorder (GAD)

\begin{tabular}{lccc}
\hline Koefisien & $R$ & $R^{2}(R$ & Signifikansi \\
& & Square $)$ & \\
\hline Pengaruh & & 0.465 & $<0.001$ \\
FNE terhadap & 0.682 & $(46.5 \%)$ & \\
GAD & & & \\
\hline
\end{tabular}

Mengacu pada Tabel 2 di atas, bisa ditarik kesimpulan bahwa peran fear of negative evaluation (FNE) terhadap generalized anxiety disorder (GAD) adalah signifikan. Prosentase peran ini adalah sebesar 46.5\%, sebagaimana bisa dilihat dari nilai $R^{2}$.

\section{Diskusi}

Penelitian ini bertujuan untuk menguji peran fear of negative evaluation (FNE) terhadap generalized anxiety disorder (GAD) pada remaja SMA. Hasil penelitian mendukung hipotesis penelitian yang menyatakan bahwa fear of negative evaluation (FNE) berperan signifikan dalam menjelaskan tinggi-rendahnya generalized anxiety disorder (GAD). Peran tersebut membuktikan bahwa tingginya FNE menjelaskan tingginya GAD, dan sebaliknya, rendahnya FNE menjelaskan rendahnya GAD pada remaja.

Watson dan Friend (1969) mendefiniskan FNE sebagai perasaan takut terhadap penilaian orang lain, distress berlebihan karena penilaian negatif, dan ekspektasi terkait penilaian negatif dari orang lain. Lebih jauh dikatakan bahwa seseorang yang memiliki kecenderungan FNE tinggi akan menjauhi hal-hal yang dapat membuatnya dinilai oleh orang lain, walaupun belum tentu benar atau belum diketahui penilaian tersebut bernilai positif atau negatif.

Tingginya FNE menghambat individu dalam berkomunikasi dan berinteraksi dengan orang lain. Pernyataan ini didukung oleh Teori Hierarki Kebutuhan dari Maslow (dalam Santrock, 2013), yang mengatakan bahwa terhambatnya pemenuhan kebutuhan-kebutuhan fisiologis, perasaan aman, kasih sayang, dan penghargaan, akan berdampak pada terhambatnya pemenuhan kebutuhan pada hierarki di atasnya, yaitu kebutuhan aktualisasi diri. Esensi manusia adalah makhluk sosial, yang bermakna bahwa setiap individu tidak dapat terlepas dari kehidupan di lingkungannya. Hal ini berimplikasi bahwa ketika individu yang memiliki FNE tinggi secara terpaksa harus melakukan interaksi sosial, maka yang akan terjadi adalah munculnya kekhawatiran sebagai indikator utama dari GAD.

Connolly, Simpson, dan Petty (2006) memberikan informasi bahwa social anxiety merupakan kelompok anxiety disorder, yang berhubungan dengan GAD, panic disorder, agoraphobia, selective mutism, separation anxiety disorder, dan specific phobias. Penelitian ini menemukan bahwa tingginya FNE berperan signifikan dalam menjelaskan tingginya GAD pada remaja. Temuan ini sesuai dengan pernyataan Sluis dan Boschen (2014) bahwa FNE merupakan faktor yang mempengaruhi kinerja otak dan, pada akhirnya, gangguan ini menimbulkan gangguan perilaku, seperti GAD sebagai contoh.

Penelitian ini menemukan bahwa perempuan lebih cenderung memiliki FNE lebih tinggi dibandingkan laki-laki. Menurut Watson dan Friend (1969), salah satu aspek di dalam FNE adalah stres akibat kritik atau penilaian dari orang lain. Apabila dikaitkan dengan informasi yang diperoleh dari Hall dan Schmid Mast (2008), dapat disimpulkan bahwa perempuan lebih empatik dan intuitif daripada laki-laki. Hal ini menyebabkan kepekaan yang lebih tinggi pada perempuan, termasuk juga terhadap kritik, yang menyebabkan perempuan lebih rentan mengalami stres ketika memikirkan kritik secara berlebihan.

Penelitian ini juga menemukan bahwa perempuan cenderung memiliki GAD yang lebih tinggi dibandingkan laki-laki. Hal ini bisa dikaitkan dengan beberapa faktor yang mempengaruhi GAD seperti yang disebutkan oleh Page (dalam Rufaidah \& Rharisti, 2009). Salah satu diantaranya adalah faktor ketahanan 
fisik. Dilansir dari CNN Indonesia ("Wanita hidup lebih lama namun punya fisik lemah", 2016), perempuan memang memiliki fisik yang lebih lemah dibandingkan dengan laki-laki. Perbedaan ketahanan fisik inilah yang menyebabkan perempuan memiliki kondisi mental yang lemah, yang membuat mereka lebih rentan mengalami kecemasan dibandingkan dengan laki-laki.

Penelitian yang menguji peran FNE terhadap GAD di Indonesia relatif masih jarang. Dengan menguji keterkaitan antar dua variabel tersebut, penelitian ini dengan demikian bisa memberikan referensi bagi studi-studi berikutnya di Indonesia. Secara spesifik, penelitian ini menemukan peran FNE terhadap GAD sebesar $46.5 \%$. Prosentasi sisanya, yaitu $53.5 \%$, dengan demikian mencerminkan peran faktor-faktor selain FNE dalam menjelaskan GAD. Faktor-faktor lain tersebut mencakup, misalnya, stress keuangan dan kepercayaa-diri yang rendah (Farrer, Gulliver, Bennett, Fassnacht, \& Griffiths, 2016), intoleransi terhadap ketidakpastian (Yook, Kim, Suh, \& Lee, 2010), dan lain-lain, yang bisa diuji dalam penelitian lanjutan. Terlepas dari keunggulan sebagaimana dipaparkan di atas, salah satu kelemahan dari penelitian ini adalah desain penelitian yang bersifat korelasional. Implikasinya adalah bahwa peran FNE terhadap GAD pada remaja tidak bisa dinyatakan sebagai peran yang bersifat kausatif. Untuk menutupi kekurangan ini, penelitian lanjutkan bisa menerapkan desain eksperimental dengan tujuan menguji sejauh mana NFE berpengaruh atau berefek terhadap GDA pada remaja.

\section{Daftar Pustaka}

2018, Jumlah penduduk Indonesia mencapai 265 juta jiwa. (2018, Mei 18). Katadata.co.id. Diakses dari https://databoks.katadata.co.id/datapub lish/2018/05/18/2018-jumlahpenduduk-indonesia-mencapai-265juta-jiwa
American Psychological Association. (2016). Diagnostic and statistical manual of mental disorder ( $5^{\text {th }}$ ed.). VA: APA Publishing.

Atasoy, S., Donnelly, I., \& Pearson, J. (2016). Human brain networks function in connectome-specific harmonic waves. Nature Communications, 7, 1-10. https://doi.org/10.1038/ncomms 10340

Badan Penelitian dan Pengembangan Kesehatan Kementerian Kesehatan RI. (2013). Penyajian pokok-pokok hasil riset kesehatan dasar 2013. Diakses dari http://www.depkes.go.id/resources/do wnload/general/Hasil\%20Riskesdas\%2 02013.pdf

Beesdo, K., Knappe, S., \& Pine, D. (2009). Anxiety and anxiety disorders in childer and adolescents: Developmental issues and implications for DSM-V. Psychiatry Clin North Am, 32, $483 \quad-\quad 524$. https://doi.org/10.1016/j.psc.2009.06.0 02

Behar, E., DiMarco, I. D., Hekler, E. B., Mohlman, J., \& Staples, A. M. (2009). Current theoretical models of generalized anxiety disorder (GAD): Conceptual review and treatment implications. Journal of Anxiety Disorders, 23(8), 1011-1023. https://doi.org/10.1016/j.janxdis.2009. 07.006

Bernstein, M., Targownik, L., Sexton, K., Graff, L., Miller, N., \& Walker, J. (2016). Assessing the relationship between sources of stree and symptom changes among persons with IBD over time: A prospective study. Canadian Journal of Gastroenterology and Hepatology, $\quad 1 \quad-\quad 8$. https://doi.org/10.1155/2016/1681507

Chen, Y., Dolt, K., Kriek, M., Baker, T., Downey, P., Drummond, N., Canham, M., Natalwala, A., Rosser, S., \& Kunath, T. (2018). Engineering 
synucleinopathy-resistant human dopaminergic neurons by CRISPR-mediated deletion of the SNCA gene. European Journal of Neuroscience, $49, \quad 1-11$. https://doi.org/10.1111/ejn.14286

Connolly. S., Simpson D., \& Petty C. (Eds.). (2006). Anxiety disorders. New York: Chelsea House.

De Santis, D., Iovine, F., Brancaleone, F., Esposito, A., \& Buffardi, G. (2012). Generalized anxiety disorder: A study of integrated therapy. Journal of Psychopathology, 18, $49 \quad-54$. Diunduh dari https://www.jpsychopathol.it/issues/20 12/vol18-1/06Desantis.pdf

Djaali. (2008). Skala Likert. Jakarta: Pustaka Utama.

Farrer, L. M., Gulliver, A., Bennett, K., Fassnacht, D. B., \& Griffiths, K. M. (2016). Demographic and psychosocial predictors of major depression and generalised anxiety disorder in Australian university students. BMC Psychiatry, 16(1), https://doi.org/10.1186/s12888-0160961-z

Hall, J. A., \& Schmid Mast, M. (2008). Are women always more interpersonally sensitive than men? Impact of goals and content domain. Personality and Social Psychology Bulletin, 34(1), 144-155.

https://doi.org/10.1177\%2F014616720 7309192

Hanisch, C. (2019). Neuroscientific based therapy of dysfunctional cognitive overgene stimulus overload with an emotionSync method. (Doctoral Dissertation). Diakses dari https://www.legimi.pl/ebookneuroscientific-based-therapy-ofdysfunctional-cognitiveovergeneralizations-caused-bystimulus-overload-with-an- emotionsync-method-christianhanisch,b384158.html

Kumar. (2005). Research metodology: A stepby-step guide for beginner. London:

Sage Publications.

Rufaidah., \& Rharisti, E. (2009). Efektifitas terapi kognitif terhadap penurunan tingkat kecemasan pada penderita asma di surakarta (Tesis, Fakultas Psikologi UGM, Yogyakarta, Indonesia). Diakses dari http://etd.repository.ugm.ac.id/home/d etail_pencarian/43303

Santrock, J. (2013). Life-span development $\left(13^{\text {th }}\right.$ ed.). Jakarta: Erlangga.

Sluis, R., \& Boschen, M. (2014). Fear of evaluation in social anxiety: Mediation of attentional bias to human faces. NCBI, 45(4), $475-483$. https://doi.org/10.1016/j.jbtep.2014.06. 007

Sugiyono. (2011). Metode penelitian kuantitatif, kualitatif dan $R \& D$. Bandung: Alfabeta.

Supingah, I. (2018, February 10). Orang tua perlu paham cara menghadapi remaja. Suarasurabaya.net. Diakses dari https://www.suarasurabaya.net/kelanak ota/2018/Orang-Tua-Perlu-Paham-

Cara-Menghadapi-Remaja/

Sutrisno, E. (2013). Manajemen sumber daya manusia. Jakarta: Kencana.

Wanita hidup lebih lama namun punya fisik lemah. (2016, March 20). Cnnindonesia.com. Diakses dari https://www.cnnindonesia.com/gayahidup/20160319140225-255118447/wanita-hidup-lebih-lamanamun-punya-fisik-lemah

Watson, D., \& Friend, R. (1969). Measurement of social-evaluative anxiety. Journal of Consulting and Clinical Psychology, 33, $448 \quad-\quad 457$. https://doi.org/10.1037/h0027806

World health statistics 2017: Monitoring health for the SDGs, sustainable development 
goals. (2017, May 17). World Health

Organisation. Diakses dari

https://apps.who.int/iris/bitstream/hand

le/10665/255336/9789241565486-

eng.pdf;jsessionid=D0395E79FFA023

3FB4B9F0BE5EEEBC6E?sequence $=1$

Yook, K., Kim, K. H., Suh, S. Y., \& Lee, K. S.

(2010). Intolerance of uncertainty, worry, and rumination in major depressive disorder and generalized anxiety disorder. Journal of Anxiety Disorders, 24(6), 623-628. https://doi.org/10.1016/j.janxdis.2010. 04.003

Yuniardi, M. (2017). Intolerance of uncertainty, social anxiety and alcohol use among students in the United Kingdom and Indonesia (Thesis, Institute of Neuroscience, Newcastle, United Kingdom). Diakses dari https://theses.ncl.ac.uk/jspui/bitstream/10 443/3962/1/Yuniardi\%2C\%20S.\%202017 .pdf 